Kajian Malaysia, Vol. 36, No. 1, 2018, 1-24

\title{
THE GOLDEN ERA OF THE MALAYSIAN FILM INDUSTRY: CROSS- CULTURAL DIALOGUE AND NEGOTIATIONS OF ETHNICITY IN A BUDDING NATION
}

\section{Angeline Wong Wei Wei ${ }^{1 *}$, Shanthini Pillai ${ }^{2}$ and Ong Puay Liu ${ }^{1}$}

${ }^{1}$ Institute of Ethnic Studies (KITA), Universiti Kebangsaan Malaysia, Selangor, MALAYSIA

${ }^{2}$ School of Language Studies and Linguistics, Universiti Kebangsaan Malaysia, Selangor, MALAYSIA

*Corresponding author: angelinewww@gmail.com

Published online: 27 April 2018

To cite this article: Wong, A.W. W., S. Pillai and P. L. Ong. 2018. The golden era of the Malaysian film industry: Cross-cultural dialogue and negotiations of ethnicity in a budding nation. Kajian Malaysia 36(1): 1-24. https://doi.org/10.21315/km2018.36.1.1

To link to this article: $\mathrm{https}: / / \mathrm{doi} .0 \mathrm{rg} / 10.21315 / \mathrm{km} 2018.36 .1 .1$

\begin{abstract}
The period of the 1950s to the late 1960s has often been touted as the Golden Era of the Malaysian film industry. This paper examines the extent to which films of the Golden Era, specifically P. Ramlee's Sesudah Suboh (1967) and Gerimis (1968), i.e. two significant films of the era which portray stories about inter-ethnic romantic relationships, visualise the possibilities of inter-ethnic engagement through the films' narrative and the implied issues of ethnic and cultural differences. The discussion highlights the fact that there are significant moments of inter-ethnic dialogue and engagements between the characters within the narratives of the two films which outweigh the evidences of inter-ethnic prejudices that are portrayed in the films. The main conclusion that is derived from the film analysis is that the two films are significant spaces through which the borders between identities and cultures can be negotiated in the form of meaningful dialogue and engagement.
\end{abstract}

Keywords: Malaysian, film, cross-culture, inter-ethnic, dialogue

\section{INTRODUCTION}

Many Malaysians today still reminisce fondly of the Malay films of the 1950s to the mid-60s as films which featured nostalgic memories of what is often perceived as the good old days of Malaya. McKay in his article, "The Golden Age", refers to 
the films of the era as films of the golden era which portrayed a sense of "optimism in dealing with the challenges that lay ahead for a postcolonial society, tackled the threats posed to traditional values by embracing urbanity" (McKay, 2011: 208). The golden era films produced at the height of Malaysia's film history are often described as films which portray identities that are fluid and subject to negotiations. Even though the films mainly represented the Malays, they showed a sense of openness in how the Malay ethnic group in the films of the golden era was portrayed. For instance, Amir Muhammad, in his review of Malay films from 1948 to 1973, suggests that issues such as religion, ethnicity and gender were not rigidly portrayed in the films. His review of Sri Mersing (1961), a film directed by Salleh Ghani about the alienation of a newcomer in a Malay kampong, highlights the way in which the film interrogates the seemingly monolithic Malay identity using its depiction of intra-ethnic differences within the Malay kinship system of different Malay states (Amir, 2010: 205). Hussein Haniff's 1965 film, Jiran Sekampong (translated as Village Neighbours) is another film which portrays the plurality of the Malay cultural identity (Ramani, 2005). Malay films produced at the time, especially the ones directed by P. Ramlee, Hussain Haniff and M. Amin, were seen as works that have progressively dealt with the socio-cultural issues of the budding postcolonial nation.

However, the openness and vibrancy of the films of the golden era of Malaysia did not often include the engagement between people of different ethnic backgrounds in the multi-ethnic society. A closer look at the films and the film industry of the golden era shows that the representations were mainly focused on the Malay social imaginary. Millet states in Singapore Cinema (2006) that the central focus of the Malay film industry of the studio era in the 1950s and 1960s was to produce "Malay movies portraying authentic Malayness" (Millet, 2006: 36). Malay actors mainly took the center stage in most films that featured stories about the Malay socio-cultural realities. The focus on the Malay wordviews in films of the Golden Era reflects the dominance of the Malays as "the indigenous people in the country" (Cheah, 2007: 43).

This paper investigates the extent to which cross-cultural dialogue and negotiations are depicted in two films produced in the golden era of Malay films by iconic film filmmaker P. Ramlee, namely Sesudah Suboh (After the Dawn, 1967) and Gerimis (Light Rain, 1968). These were the only two films produced in the 1960s which were explicitly about inter-ethnic relationships. Prior to the 1960s, there were two films which predominantly depicted the theme of interethnic engagement - Seruan Merdeka (Freedom Call) (1946) and Selamat Tinggal Kekaseh-ku (Goodbye, My Love, 1955). These two films, as well as Sesudah Suboh and Gerimis, were the rare ones of the Golden Era which explicitly portrayed interethnic interactions. According to Hassan and Wong, Seruan Merdeka was directed by B. S. Rajhans and "featured a theme or racial unity: a Malay and Chinese youth 
leading the underground movement against the Japanese, a multiracial treatment that was rare for the time" (Hassan and Wong, 2002: 302). It was the first preindependence Malayan film which dealt with the notion of patriotism and multiethnic unity which was a rare social phenomenon portrayed on screen at the time. As for Selamat Tinggal Kekaseh-ku, both Van der Heide (2002) and Hassan (2013: 47) have described it as an adaptation of Devadas, a popular Indian story about an inter-ethnic love story between the Malay protagonist and a Chinese girl. Interestingly, the film portrays the theme of an unfruitful relationship of which Hamzah Hussin sees as an intentional focus of the film to "avoid any inter-ethnic prejudices and suspicions" (2004: 70). The effects of inter-ethnic engagement tend to be feared and negatively construed due to predetermined ill feelings towards the Other.

In view of the engagement that takes place between the protagonists of Sesudah Suboh and Gerimis, this paper seeks to explore the possibilities and challenges of inter-ethnic relationships in the context of the film's narrative as well as the multi-ethnic realities of postcolonial Malaysia. The paper concludes by reflecting on the significance of how inter-ethnic relationships are visualised in Sesudah Suboh and Gerimis in relation to the issues of border crossings and negotiation of differences in multi-ethnic Malaysia. The following section provides a brief overview of the multi-ethnic history of Malaysia to form the contextual basis of the analysis of the films.

\section{Multi-Ethnic Malaysia: A Brief Overview}

Multi-ethnicity and cultural diversity have been a characteristic of Malaysia since pre-colonial days. Hefner describes the Malay Archipelago as "conducive to interethnic collaboration and rich cultural exchange" (2001: 13). People from different localities came to the major crossroads of Asia for the vibrant trade and there existed a picture of diversity that was defined by less rigid ethnic boundaries. There were no fixed and centralised power structures and national boundaries but commercial dynamism based on "networked collaboration of many small states" (Hefner, 2001: 13). Instances of cultural openness were evident as intermarriages between Bugis and Malay royalties, Chinese and Malays, as well as Indian Muslims and Malays were not uncommon (Hirschman, 1986: 338). It was a time when there were no hardened ethnic barriers until diversity had to be managed by colonial administrations through political means.

While pre-colonial Malaya saw cultural mobility through economic vibrancy, migration and inter-cultural marriages, the colonial ruling of Peninsular Malaya implemented the earliest "systematic" race-based governance via the divide-and-rule policy. The segmentation of the multi-ethnic nation into the homogenous ethnic categories of Malays, Chinese, Indian, and Others has been 
in place since colonial days. According to Hirschman, "the twentieth century structure of 'race-relations' of Peninsular Malaysia is largely a product of social forces engendered by the expansion of British colonialism of the late nineteenth century" (1986: 331). The divide-and-rule strategy employed during the British administration played an integral part in setting up and fossilising the ethnic categories. Focusing on the ethnic classifications used in the census from the beginning of the nineteenth to mid-twentieth century, Hirschman (1987) shows how racial categories and definitions went through gradual but drastic changes, of which they were subjected to re-definitions over time. Having traced the evolving ethnic categories that were stated in the census, he reveals that the people of the Federated Malay States and the Straits Settlements were labelled according to regional locations, dialect communities and variedly constructed ethnic group names. Minor categories (e.g. dialect groups and regional group categories) tended to get replaced by the monolithic categories of "Malay", "Chinese", and "Indian". The homogenous ethnic group names that were crystallised in colonial days have been taken as fixed entities of ethnic categorisation in postcolonial Malaysia.

Against the background of the segregated ethnic demographics of Malaysia, the relationship between inter-ethnic communities has always been unstable, especially since the post world-war period. Shamsul (2012: 6) critically labeled the state of ethnic relations in the period from 1945 to 1960 as a "Conflict Era" due to strong inter-ethnic suspicions, especially between the Malay and Chinese communities which were prevalent due to issues of allegiance and betrayal during the Japanese Occupation. The sentiments of inter-ethnic distrust not only increased due to social, economic and political struggles, but also escalated in the processes of negotiations that were held close to the independence of the Malayan State (Shamsul, 2012: 7). Not all was in vain as "ethnic bargaining" took place in the formation of the Communities Liaison Committee (CLC) in 1949 as the British's initiative to assist in alleviating inter-ethnic tensions. The outcome of the CLC was the consensus reached in committing to the political, power-sharing coalition between Malay, Chinese and Indian leaders. The state of ethnic relations in the subsequent historical period from 1961 to 1970 is labeled as the "Stable but Tensed Era" by Shamsul (2012: 9). The challenges of being a budding multi-ethnic nation became more critical as Malaysia was formed when the Federal State of Malaya, Sabah, Sarawak and Singapore agreed to be part of this nation on 16 September 1963. The constant inter-ethnic prejudice and fear of the Other, specifically between the Malay and Chinese communities, gave rise to two ethnic riots that occurred in Singapore in 1964 and Kuala Lumpur in 1969 respectively (Shamsul, 2012: 9). As a result of the 1969 ethnic riots, various top-down governmental measures such as the affirmative economic policy or the New Economic Policy (NEP) were formulated with the aim of strengthening the ethnic cohesiveness within the nation. In short, the official history of multi-ethnic Malaysia shows that there has 
been the constant need for the safeguarding of the socio-economic, socio-political and socio-cultural interests and positioning of each ethnic community as a means of managing the multi-ethnic nation.

\section{Cross-cultural Dialogue and Negotiations}

In all cross-cultural dialogues and negotiations, the existence of multiple interethnic realities has to be taken into consideration in order to achieve consensus. As it has been mentioned earlier, the culture of inter-ethnic bargaining and negotiation began with the CLC in Malaysia in 1949 when the leaders of each of the three major ethnic communities gathered to dialogue about their shared interests for the new nation. Since then, the collaborative powers that have had to negotiate various conflicting perspectives on issues of language, education, religion, economic development and political directions. On the other hand, the multi-ethnic experiences of the people on the ground are also varied and may or may not cohere with the authorities' rigid ways of managing the multi-ethnic society.

One way of perceiving ethnic relations and the fluidity of how a nation is imagined is to explore Shamsul's concept of the "nations-of-intent" which looks at various competing realities of "the authority-defined" and "the everyday-defined" in the visualisation of the nation of their desire (1996: 323-324). According to Shamsul, nation building is an on-going process of constant dialoguing between the different voices of a nation, not just a single imagination of a unitary and absolute authority. It is precisely in the dialogue between different ethnic voices that the complexities of the multi-ethnic social fabric of the nation are able to challenge the divisive boundaries between each community. Without inter-ethnic dialogue and negotiation, the spaces for the engagement between Malaysian are erased. In other words, the minorities who do not fit into any categories are inevitably marginalised. It is henceforth important to explore the multi-ethnic dynamism in society from both the perspectives of the authority and the everyday realities to negotiate between diverse realities. This is a crucial approach to promoting inclusivity as identity is more dynamically perceived as fluid and able to be constructed and re-constructed (Hall, 2000: 17). The need for dialogue between different voices is particularly significant to the Malaysian context as Malaysia is a nation state which is still going through the daily process of social cohesion towards the imagining of an ideal nation for all Malaysians. However, the outcome of the process is less important than the process itself because the multiplicity of the imagined nation and the engagement between different voices ultimately characterise multi-ethnic Malaysia.

Interestingly, cross-cultural dialogue and negotiations can be explored through the two selected films as they feature the relationship between Malaysians of different ethnic backgrounds. In fact, most films portray diverse cultures and 
multiple worldviews as they are narratives about realities of life. Thus, the selected films of the golden era in this paper can be seen as a reflection of the possibilities and challenges faced in inter-ethnic engagement. The following section briefly discusses the history of Malayan/Malaysian filmmaking of the golden era by focusing on the extent to which films of the golden era were diverse in nature.

\section{MALAYSIA'S GOLDEN ERA OF FILMS}

The appeal of the golden era Malay films is often attributed to the mix of the local and global cultural influences in filmic style and narration. One of the reasons why Malay films of the time seemed to attract audiences across ethnicities could be due to the universal and global aspect of the early Malay films. McKay sees the vibrancy of the golden era of the film industry in terms of the spaces it allows for more fluid representations than those of contemporary mainstream Malaysian films, as he states:

While appearing ethnocentrically Malay, these films contributed to the creation of collective identities, drawing broadly Malaysian audiences. The Malayness of those films spoke to more than just Malays - it spoke a new national society and its shared challenges.

(McKay, 2011: 209)

Mckay's critique of Malay films from the golden era highlights the films' characteristics of shared cultural identities and interests which appealed to the viewership of not just the Malay communities, but those from different ethnic backgrounds. Hassan and Wong (2002) also put forth that the Indian style of "melodrama, overacting, dance and songs" which dominated the Malay film scene of the golden era had constructed the multi-cultural Malay screen image. What is interesting about the Indian style of local Malay films is that it seemed to have appealed to the local audience, regardless of ethnicity differences, with the integration of multiple cultural influences. This could be a contributing factor to its appeal across ethnic boundaries.

This said, however, instances of inter-ethnic engagement were rarely portrayed in the golden era Malay films as most films of the time centred on issues pertaining to Malay identity due to the fact that the Malay culture is to be the dominant, national culture. Seldom were there stories about the multiplicity of various ethnic communities and the dynamism of inter-ethnic social relationships in spite of the multi-ethnic demographic of the budding nation. Characters of other ethnicities were often depicted as minor and stock characters in the Malay 
films (Millet, 2006: 37). For instance, Millet has noted that non-Malay characters in the films of the golden age were stereotypically "laughing coolies, shrewd businessmen, and the like. Indian characters were even rarer, ironic considering the majority of these movies were directed by Indians" (Millet, 2006: 37). Films like Ali Baba Bujang Lapok (1961) and Do Re Mi (1966) by P. Ramlee were among the films which depicted the non-Malay characters as racial stereotypes. The Chinese characters, i.e. the cobbler and debt collector, from Ali Baba Bujang Lapok and Do Re Mi respectively, were depicted in the image of the Chinese stereotype of the apek (an old Chinese man who speaks Malay with a stereotypical Chinese colloquial slang). The attire of the apek is the sam fu, a traditional Chinese attire often used to represent the oriental Chinese-ness from mainland China. As minor roles in the films, the flat characters were depicted as "stingy" and money-minded in a comical way, a common form of the Chinese ethnic stereotype. In Do Re Mi, the character of the creditor who is an Indian man displayed the features of an Indian sami (priest) who speaks in colloquial Malay with a Tamil accent. These ethnic stereotypes can be challenged through more diverse representations of ethnic characters in films.

This is not to say that stereotypes were the only feature in the depiction of other ethnic communities. Inter-ethnic exchanges were also featured in some of the films of the golden era. For instance, the Chinese cobbler in Ali Baba Bujang Lapok engages with one of the pirates and tells him the fact that he has lived in Malaya for generations. The pirate then seems to see the cobbler as a fellow citizen as he repeats his affirmation of the cobbler's claim about his sense of belonging in the country. These brief moments of inter-ethnic dialogue and solidarity were however often minimal and undeveloped. If expanded, they could have reflected a step beyond the portrayal of merely ethnic stereotypes. The ethnic stereotypes that are featured in the films do bear witness to the presence of diversity in a multiethnic community, but at the same time reveal a lack of deeper engagement between the different ethnic groups. The heavy use of ethnic stereotypes in most films of the time implies that there was an obvious division between different ethnic communities.

Towards the end of the golden era of Malay film, two interesting films directed by P. Ramlee stood out as being revolutionary in the depiction of interethnic relationships. The films, Sesudah Suboh and Gerimis were produced at the dawn of the 1969 ethnic riot. It was a time in the history of Malaysia during which Malaysians were going through the negotiation of political differences in the context of a budding postcolonial nation. Johan (2016) states that films with themes of multi-ethnicity were scarce during the golden era of the Malay film production and that there were "attempts later on by P. Ramlee to do so but by then it was too late, too little". Furthermore, Ramlee's other films mostly represented issues related to the Malay society using humour and parody (Hassan, 2013: 58). 
Hence, both Sesudah Suboh and Gerimis are significant in that they portray the romantic relationships formed between individuals of different ethnic identities. The two films are selected for the analysis in this paper as they deal with issues of cross-cultural dialogue and negotiations.

The two films can be analysed in terms of various interactions between characters of different ethnic backgrounds. Mahyuddin critically posits that Gerimis "constructs and dissolves the 'other' in the space that is allowed by the idea of modernity in society" (2011: 81). Mahyuddin further questions the extent to which inter-ethnic accommodation can possibly take place in spite of the film's implicit suggestion that ethnic bias can be done away with. Questions about the depth in the portrayal of inter-ethnic engagement in both films need to be explored through the films' narrative. In the following section, Sesudah Suboh and Gerimis are closely examined in terms of how they can lead to further thoughts on the representation of ethnic identities and the engagement between ethnic communities in the golden era of the Malaysian film industry.

\section{Cross-cultural Dialogue and Negotiations of Ethnicity in Sesudah Suboh and Gerimis}

The film, Sesudah Suboh centres around an inter-ethnic relationship that is forged between Ariffin, a Malay man, Alan, his good friend who is an ethnic Chinese and the romantic relationship that Ariffin forms with Alice, also an ethnic Chinese. The latter begins as a result of Ariffin's estrangement from his family. The film reveals various details about the ethnic identities and cross-cultural dialogues and negotiations that involve the characters, from its opening credits right up to the conclusion of the film. As Amir Muhammad has pointed out, the film showcases "the most multicultural cast we have seen" (2010: 368) and this is clearly shown throughout the film. The official poster of the film, as shown in Figure 1, depicts the main characters, namely Ariffin, Salmi, Alice and Salim. It visualises the gist of the film - a story revolving around multi-ethnic characters and their relationships. What stands out in the composition of the poster is the position of Alice that is close to the centre of the picture. Her image is the largest in size relative to the images of the other characters and her ethnic identity is evident as she adorns the cheongsam, a traditional Chinese cultural attire. Cultural attires often signify cultural identity and differences. The centering of Alice's character foreshadows the role she plays in reconnecting the family ties of Ariffin and his family, an act of helping others regardless of ethnic differences. Thus, the position of Alice's cheongsam at the centre of poster not only highlights her importance in the film, but also the ethnic identity and cultural affiliation that she represents. The poster itself represents an image of the multi-ethnic nation - the presence of diversity and engagement between Malaysians of different ethnic backgrounds and culture. 


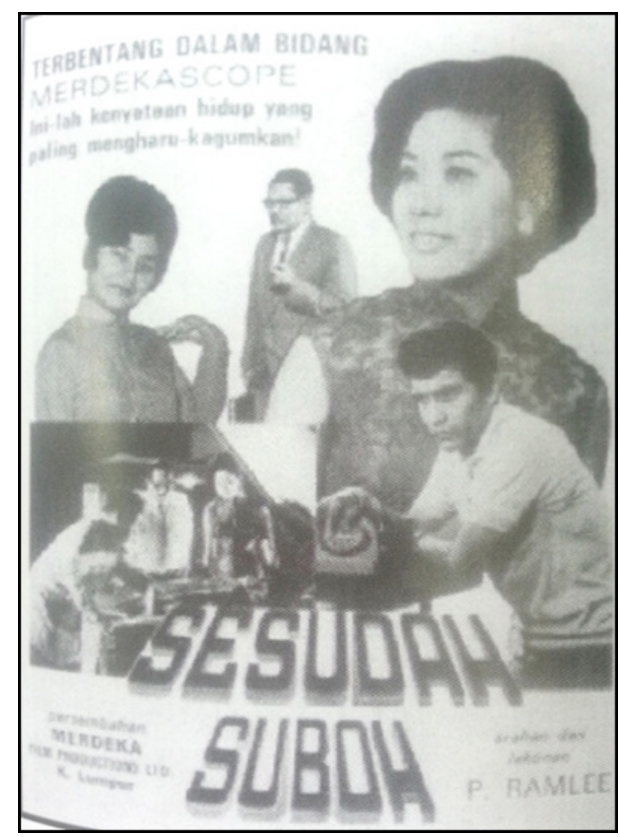

Figure 1: Film poster of Sesudah Suboh.

However, it is interesting to note that multi-ethnicity is represented in terms of how ethnic categories are distinctly highlighted in the opening credits of Sesudah Suboh, as shown in Figure 2. The different ethnic identities are introduced as Keluarga Melayu (Malay family), Keluarga Tiong Hua (Chinese family) and Keluarga India (Indian family). The categorisation of the families as ethnic entities highlights the cultural differences between them, such as their names and attire. It can be read as an apparent focus on their ethnic differences right from the beginning of the film. The order of Malays, Chinese and Indians in the sequence of introducing the characters could also be seen as an allusion to the tripartite sociopolitical composition of the Malaysian plural society, where the Malays are the majority community, and the Chinese and Indians are the minorities. This social structure is a reflection of the segregated ethnic demographic of the colonial and neo-colonial nation states. The representation of the divided ethnic categories is not only an emphasis of how the ethnic characters are exclusive from each other, but also the homogenous cultural features within each ethnic category. This focus on the Malay, Chinese and Indian families reflects the diversity of multi-ethnic Malaysia which is often characterised by the emphasis on ethnic and cultural boundaries. The labelling and grouping of the characters according to their ethnic differences semiotically reflects how ethnicity is a significant marker of identity in the multi-ethnic society. 


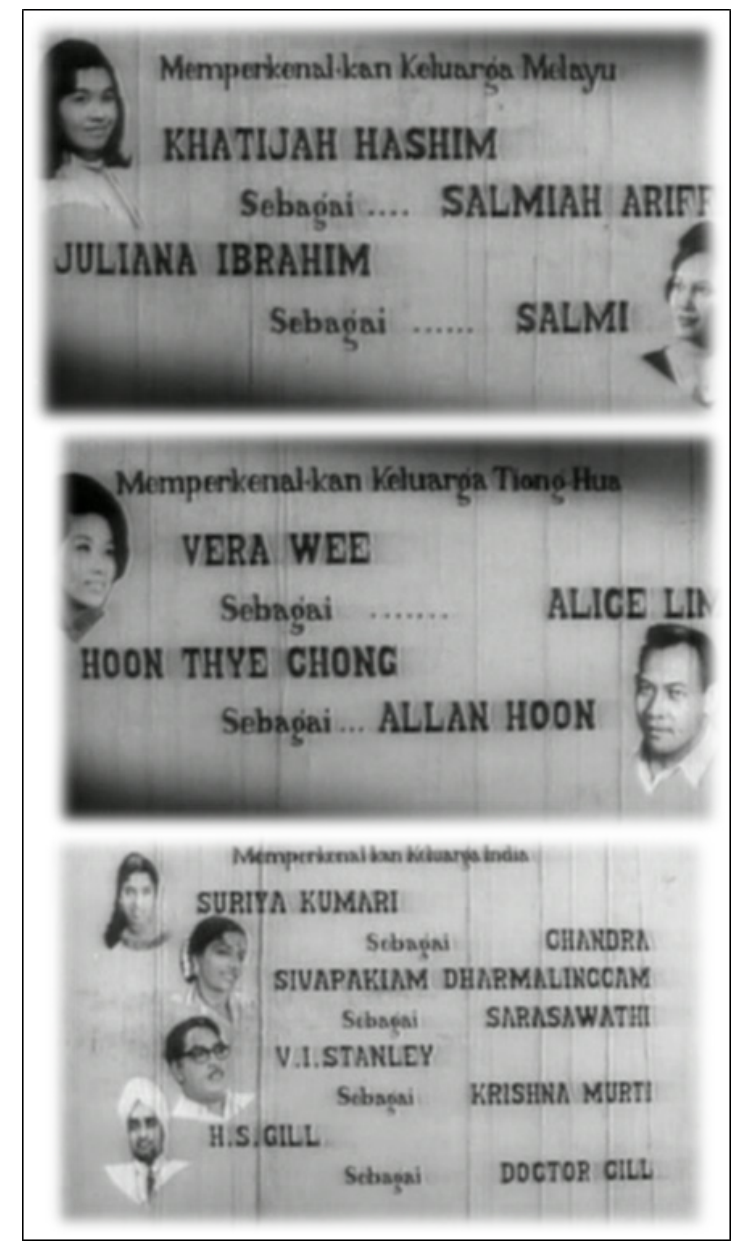

Figure 2: Screenshots of the Sesudah Suboh film credits.

In terms of the film's narrative, the interactions between the multi-ethnic characters can be seen as instances of border crossings. Such instances are weaved into the story of the film. Sesudah Suboh portrays a Malay family of which its members face the challenges of upholding familial love and commitment with each other. The film begins with the character of Ariffin (played by P. Ramlee) going about his daily work in his own pace while his family members are too busy with their daily endeavours to interact with him. His wife, Salmi, is pre-occupied with charity work to the point of neglecting her husband and family, while his two children, Salim and Salmiah, are estranged from their father, the reason being the lack of quality time spent together as a family. Ariffin, saddened by the alienation from his family members, meets Alan, an ethnic Malaysian Chinese 
whom he befriends and confides in. This is where the engagement between them is formed without any concerns of ethnic differences. Alan shows his empathy to Ariffin by constantly consoling him and advising him to be reconciled with his family. He generously buys Ariffin gifts to be presented to his children, and movie tickets for Ariffin and his wife to watch a movie together. Figure 3 shows the scene and dialogue in which Ariffin, having received Alan's gifts, is puzzled by Alan's kind gestures, and so he asks Alan the reasons behind his good deeds. Alan replies that even though they are of different ethnic backgrounds, they are "sons of Malaysia" (Malaysians), and that the duty of Malaysians is to help each other. The dialogue explicitly points to the need for cohesion among Malaysians and that solidarity should be present between members of the multi-ethnic nation. This is further reinforced by the aesthetic framing of this scene - the balanced, medium shot of Ariffin on the left and Alan on the right symbolically portrays the interaction between them on equal grounds. Ariffin appears to be touched by Alan's kind gestures and constantly shows his gratitude towards Alan's friendship and assistance. Hence, Alan's statement and the dialogue he shared with Ariffin demonstrate the possibility for cross-cultural dialogue towards the establishing of closer connections among Malaysians. The moment of inter-ethnic solidarity is evident here, where national identity, the imagined sense of belonging to the nation, bridges ethnic differences.

Other instances of inter-ethnic engagement are evident in the relationship formed between Ariffin and Alice, an ethnic Malaysian Chinese woman who becomes Ariffin's lover. As Ariffin gets rejected by his family in his efforts to make peace with them, he meets Alice who comes into his life at a moment when none of his family members would interact with him. Alice arrives at Ariffin's house to ask for his help when her car breaks down outside his house. Since then, they are often together as Alice would help Ariffin with his business. It is not long before Ariffin falls for the kind hearted Alice who is there for him when he does not have any one to turn to. Their relationship grows as they spend more time together. In their relationship, Alice is sensitive to Ariffin's Muslim identity and religious practices. A significant example of how she shows her respect for Ariffin's culture is reflected in the scene (refer to Figure 4) where they are having a meal at Alice's house. Alice assures Ariffin that the food is halal (permissible to be consumed according to the Islamic law) because it is prepared by Aminah, her Muslim Malay helper. Ariffin expresses his gratitude for Alice' recognition of the religious sensitivities and the respect shown. The exchanges between them show that there is no ignorance on Alice's part in accommodating Ariffin by showing her respect for his cultural practices. This instance in the film also reflects the everyday reality of multi-ethnic Malaysia where Malaysians inevitably recognise and respect each other, and that many are generally sensitive to the issue of food as a signifier of one's identity and cultural beliefs. 


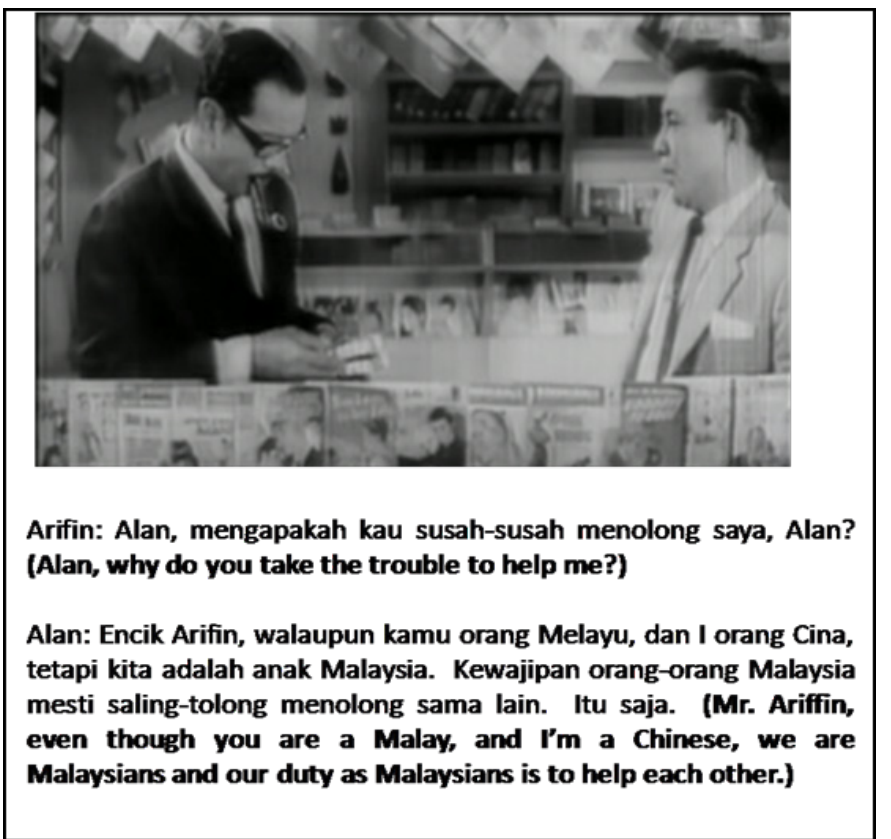

Figure 3: Screenshot of the scene in which Arifin converses with Alan about being Malaysians in Sesudah Suboh.

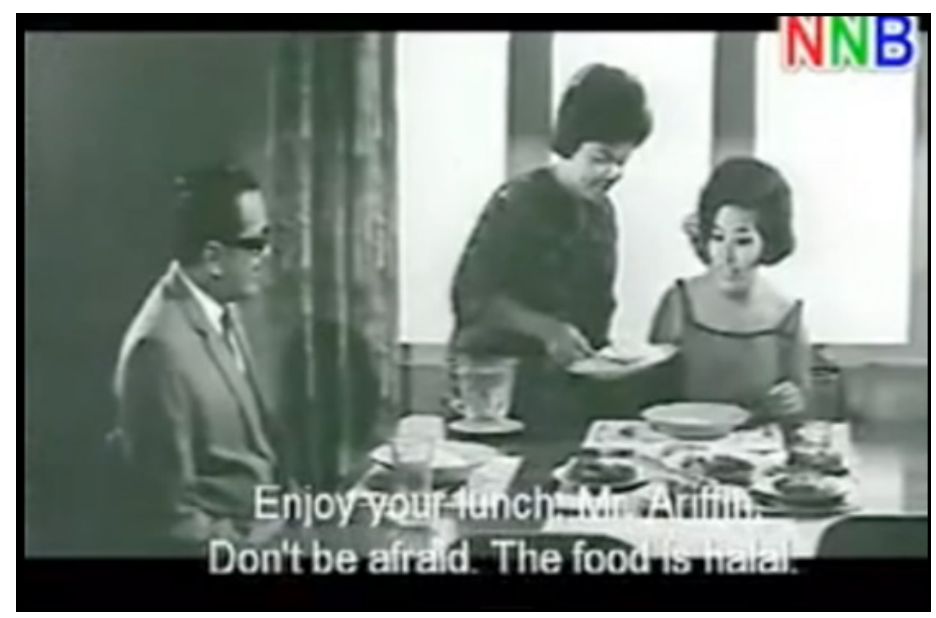

Figure 4: Screenshot of the scene in which Alice tells Arifin that the food served is halal in Sesudah Suboh.

There are other scenes that reinforce the representation of border crossing in the film. To start a new chapter in his life, Ariffin sells his bookstore to Alan for 50,000 ringgit, upon being advised by Alice, and the couple plans to move to Sabah 
to start a new life together. In the scene where Ariffin is receiving the cheque from Alan, Ariffin code switches to Mandarin when he tells Alan that he finds Alice to be an intelligent woman. Ariffin shows that he is open to speaking in Mandarin to create the sense of solidarity between them. The ability to code switch to Mandarin gives the sense of perceiving language and identity beyond ethnic boundaries. The film portrays the idea of prioritising national identity over inter-ethnic differences. It gives a positive reflection of the everyday reality of Malaysians, where crosscultural dialogue and negotiations take place among them, and that the sense of nationhood can be realised through inter-cultural dialogue.

Sesudah Suboh also portrays how one's ethnic identity can be used to overshadow one's negative impression of others. This is highlighted in the scene where Salim quarrels with his father, Ariffin. Their argument ensues when Salim confronts Ariffin that he has spotted Ariffin and Alice at a beach for a holiday in Port Dickson. Salim questions his father's action of cheating on his wife, Salmi. In the argument, Salim refers to Alice as perempuan Cina itu (or "that Chinese woman") with the negative connotation of the "Chinese woman", a seductress and "the other woman". Salim accuses his father of humiliating their family by having an affair with "that Chinese woman". The way in which Salim refers to Alice using the stereotype of perempuan Cina itu implies that her ethnic identity is highlighted as an ethnic and female stereotype. The derogatory term used also intensifies his prejudices towards the ethnic Other, as Alice is portrayed as the third party, an ethnic Chinese woman who has disrupted the family ties between Ariffin and his family. Salim's negative perceptions about the "Chinese woman" seem to be more influenced by the anger towards his father for having an affair and neglecting Salmi, Ariffin's wife. The implied message here seems to be that prejudices towards the ethnic Other are often unrelated to ethnicity, but more connected to one's personal issues. In the case of having distrust towards others, ethnicity seems to be the smokescreen that is conveniently used to reduce the visibility of other underlying problems.

The use of ethnicity as a pretext to disqualify others is further reinforced by the fact that Salim is also in an inter-ethnic relationship. While Salim shows his resentment towards Ariffin and the "Chinese woman", he is in a relationship with Chandra, his girlfriend who is an ethnic Malaysian Indian. Salim and Chandra do not encounter conflicts that are associated with their ethnic differences. They are very close to each other and would visit each other's family. In contrast to the rudeness shown to his own father, Salim respectfully greets Krishna Murti, Chandra's father using the traditional Indian hand gesture of putting both hands together at the chest, as shown in Figure 5. This is a stark contrast to Salim's disrespectful gestures shown to his father, Ariffin in an earlier scene where Salim rejects and demeans Ariffin's gift by throwing it to the floor. Having witnessed Salim's rude treatment of his father, Chandra becomes greatly troubled by Salim's 
lack of filial piety. Chandra tries to advise Salim to change his disrespectful ways but it was to no avail as she ends up arguing with him. Chandra then meets Ariffin at his bookstore and expresses her disapproval of Salim's behaviour. Her empathy and respect shown towards Ariffin are seen in her tearful apologising on Salim's behalf. Chandra clearly treats Ariffin like he is her own father, as shown in Figure 6. This is an instance of border crossing because ethnicity is not an obstacle in treating others like family. In another example, Chandra's father, Krishna Murti is a good friend of Ariffin's back in their school days. Their friendship is not uncommon where students from different backgrounds have the opportunity to engage with each other in the multi-ethnic space of the Malaysian public schools. As one with an open outlook, Krishna Murti does not object to Chandra and Salim's romantic relationship and treats Salim like his own son. In a conversation between them, he also advises Salim regarding the need to honour his father. The friendships forged between Ariffin and Salim and their non-Malay friends are significant in that they contrast the sense of alienation that Ariffin experiences at home. This contrast between Ariffin's family and friendships can be symbolically analysed as the film's attempt to shift people's perspectives regarding the seemingly problematic relationships between those of ethnic differences. The film's portrayal of the everyday realities of Ariffin, his family and friends has shown that Malaysians need to dialogue and negotiate differences that are not merely ethnic related.

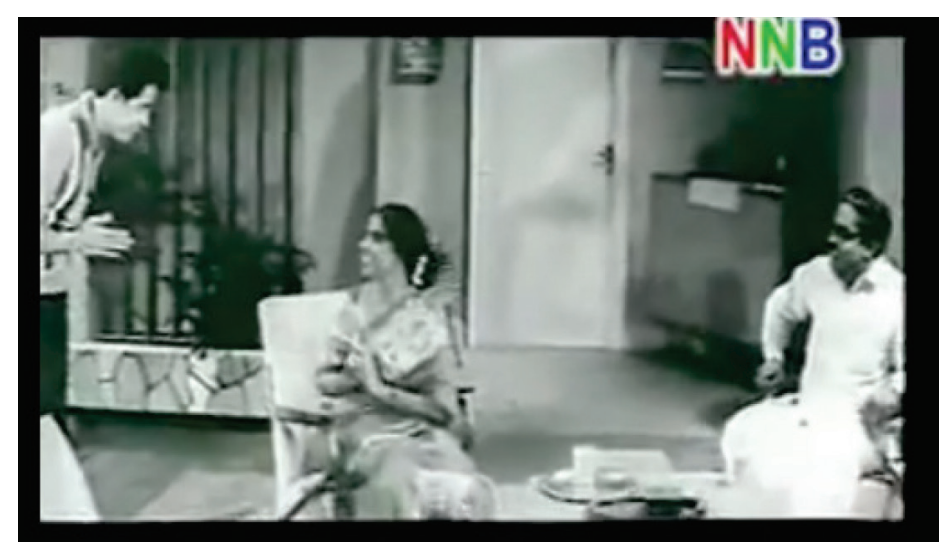

Figure 5: Screenshot of the scene in which Salim greets Chandra's parents using the Indian gestures of putting his palms together in Sesudah Suboh. 


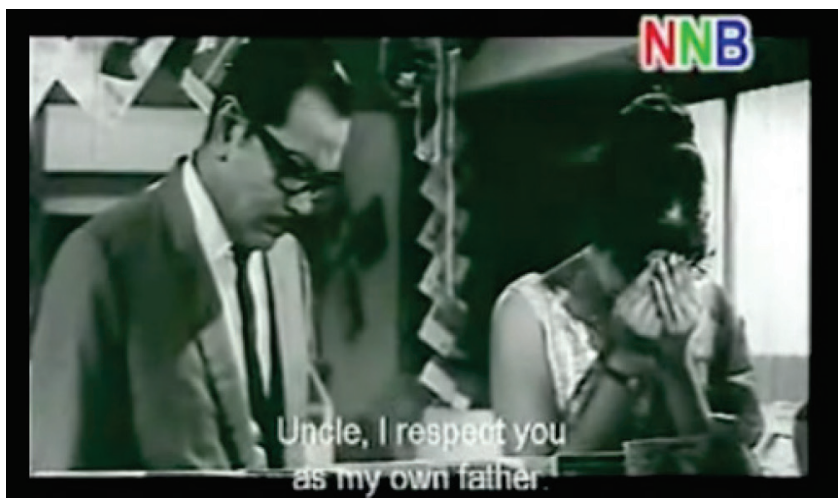

Figure 6: Screenshot of the scene in which Chandra expresses her empathy towards Ariffin.

There are also instances of inter-cultural engagements seen among the characters of the Malaysian Indian family. Chandra converses in a mix of Tamil and Malay with her parents. At certain moments, the family members converse only in Tamil, which can be alienating to non-Tamil viewers without the help of subtitles, but such scenes are made in this way to show that Malaysians are at ease with each other in spite of language barriers. Krishna Murti's wife, Sarasawathi, is also described as a culturally open person as she constantly visits her neighbours to play congkak, a traditional Malay game. This is another instance in which border crossings and engagement are explicitly revealed in the film. There are no qualms about the ethnic divide in the everyday life of Sarasawathi. Her neighbours' ethnicity is not made known, but the fact that they meet up to play the congkak together shows that inter-ethnic solidarity is evident as the Malaysian identity cuts across different ethnic backgrounds. Ethnic differences are not an issue for the characters of different ethnicities as they display the act of recognition, accommodation and respect for each other in the everyday realities.

Interestingly, a non-Malay character plays a significant part in helping the Malay family realise the importance of being together as a family. While Alice is portrayed as the "intruder" in Ariffin's family, her role in reuniting him and his estranged family members is revealed towards the end of the film. In the film's "twist", Alice informs Ariffin that they will not proceed with the plan to start a new life together. Alice and Alan then reveal to Ariffin that his "affair" with Alice is part of their plan to get Ariffin's family to repent and be re-united with him. Alan explains that he is the lawyer of Ariffin's deceased father who had asked him to give Ariffin the big sum of money left for him when Ariffin most needs it. The film ends with Ariffin's family being reconciled. It is evident from the plot of the film that it is centered on the story of restoring family values in Ariffin's family. In the process, Alice, and her husband, Alan, are positively represented as the ones to 
whom Ariffin and his family are indebted. The characters of Alan and Alice play the important, supporting roles that serve the cause of restoring family values.

Sesudah Suboh negotiates the pathways of cross-cultural dialogues and negotiation through the film's narrative and portrayal of the relationships between the characters. The instances discussed above reveal the evidences of inter-ethnic engagement made possible by the ease in which the characters interact with one another. Such evidences show the values that are shared in the relationships formed across ethnic boundaries. In spite of their differences, the characters of different ethnicities display the act of recognition, accommodation and respect for each other. Even though the opening credits show visual division, the film reveals multiple border crossings and dynamic inter-ethnic engagement. The instances where Chandra rebukes Salim for mistreating his father and Alice and Alan's intervention in Ariffin's family conflicts show that the non-Malay characters are positively depicted in the film. The film's integration of the Malay and non-Malay characters weaves in the theme of national unity. Apart from that, a message from the film could be that it takes all members of a nation to form a more open and engaging multi-ethnic nation state.

Gerimis portrays an inter-ethnic romantic relationship of Kamal, a Malay, and Leela, a Malaysian Indian. The film depicts their love story and the challenges they face in their marriage as an inter-ethnic couple. The film's poster (refer to Figure 7) displays the images of Kamal and Leela at the centre and their distinct ethnic traits. Similar to the film poster of Sesudah Suboh, this positioning of the characters implies that their inter-ethnic relationship is the focus of the film. Another significant feature of the poster is the question displayed on the top left corner of the poster as the slogan of the film: "Berlainan bangsa, berlainan keturunan...Dapatkah mereka mendirikan rumahtangga bahagia bersama untuk selama-lamanya?" (translated as "Will they, of different ethnic communities, live a blissful and long-lasting marriage together?") This question seems to foreshadow the impending conflicts in the film that may be attributed to the ethnic differences of the main characters. These symbolic features of the poster serve as explicit references to the film's emphasis on ethnic differences in an inter-ethnic relationship.

The first instance of cross-cultural engagement is seen in the bilingual feature of the first love song featured in the film. The love story begins with Kamal's admiration of Leela, a dancer in the night club where he usually paints. Kamal asks Leela if he could paint a portrait of her and she readily agrees to be his model. A significant cross-cultural feature of their relationship is the song entitled Pujaanku (translated as "The One I Adore") sung in the tune of the popular English song, "Clementine" by Kamal and Leela in separate spaces. In the duet, linguistic boundaries are crossed as Kamal renders the song in the Malay language to the response of Leela's singing of the Tamil verses. The camera focuses separately on 
Kamal and Leela and the shots intercut and overlay each other. The intersecting camera shots create the visual effect of the deep longing in Kamal and Leela to be together in spite of the different worlds that they inhabit. The crossing of linguistic borders can be symbolically analysed as a means of moving beyond cultural differences. From another perspective, people who are in love communicate beyond any linguistic boundaries.

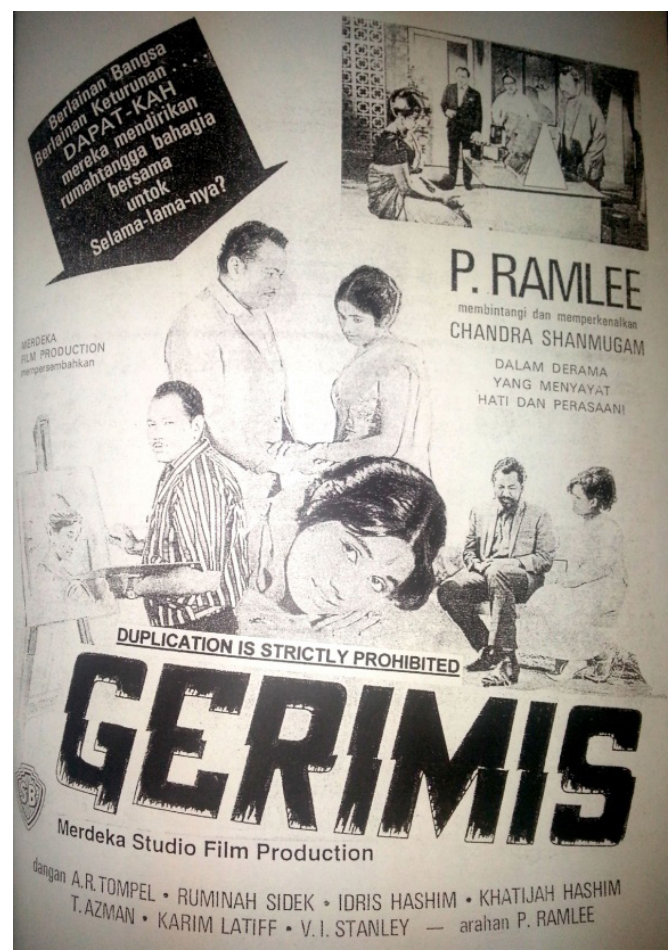

Figure 7: Film poster of Gerimis.

In the development of their relationship, Kamal and Leela face antagonism and hostility from their family members who are unable to accept their union. As their love for each other grows, Kamal asks for Leela's hand in marriage and she agrees to marry him. Kamal foresees the objections from their families and tells Leela that they will get married regardless of the circumstances. Kamal's wealthy father strongly disapproves of the marriage, even though his reasons for the disagreement are not related to ethnic differences. It seems that Kamal's father is worried about the distribution of the family's wealth which leads him to forbid his children to marry. As for Leela's family, her father is furious upon hearing that she is marrying a Malay man, as he loudly acclaims, "Apa?! Nak kahwin dengan Melayu?" (translated as "What?! Do you want to be married to a Malay man?") 
Interestingly, Leela's father utters this line in Malay, and it is the only line in Malay in the entire dialogue between him and Leela. One reason for this deliberate choice of using the national language could be that the statement is significant and needs to be heard by all Malaysians. In the rest of the dialogue, Leela's father expresses his strong objections to Leela's marriage plans in Tamil about his rejection of her daughter's need to convert to Islam. When his wife points out that their elder daughter has married an Indian who is a Christian, Leela's father argues that it is not similar to Leela's conversion to Islam. He explains that the conversion of Leela will involve the losing of her Indian identity. The father's disagreement is so strong that he disowns her as his daughter. This instance of resistance to an inter-ethnic marriage is not uncommon in the everyday realities of Malaysians because the non-Malays who are not Muslims are generally fearful of the need to convert to Islam in order to tie the knot with a Malay partner. In fact, issues of religious and other cultural conflicts are evident in any inter-ethnic relationship. Unlike Sesudah Suboh, the case of cross-cultural negotiation that is portrayed in Gerimis is largely seen through the sacrifices of Kamal and Leela in being wedded without the consent and blessings of their respective families.

A notable scene in Gerimis which portrays an instance of cultural assimilation is shown in the marriage solemnisation ceremony of Kamal and Leela in the presence of a religious $k a d i$ (a Muslim religious judge). Figure 8 illustrates the positioning of Leela at the centre of the medium camera shot of the characters. It is an interesting frontal view of Leela in the meeting with the kadi to seal the Islamic nuptial agreement. The symbolic framing of the shot implies the centering of Leela's own will in agreeing to convert to Islam and to embrace the Islamic religious practices. In contrast to Leela's father's strong objection towards her daughter's religious conversion, Leela's willingness to compromise her religion for the love of Kamal is seen as an act of inter-cultural accommodation. This scene refers to the obligatory requirement for religious conversion, i.e. the official pre-requisite of any inter-ethnic marriage between Malays and non-Muslims Malaysians. The camera focus on Leela in the scene when she gives her consent to convert to Islam shows the personal will on her part in her agreement to adopt the religious identity and assimilate its cultural practices. The issue of religious conversion in an inter-ethnic marriage is often seen as a sensitive and emotionstirring one for most non-Muslims, as Mahyuddin critically states:

Gerimis requires some space where it can negotiate the position of the dominant ethnic group and reposition the "other" in a well regulated race relations that is required by modern Malaysia. This particular space can be found in the world of marriage. Mixed marriage is considered to be one way to eradicate prejudice in ethnic relations. However, in the course of doing this, the "other" becomes a conformist, and thus, their cultural 
importance diluted; that is, the "other" loses its own sense of identity and culture in order to assimilate with the dominant cultural group.

(2011: 81)

Mahyuddin's perspectives on the meeting points between two cultures highlight both the positive and negative consequences of one's assimilation with the other ethnic group. The conjoining space of mixed marriages is indeed positive as it leads to the integration of cultures as well as the elimination of inter-ethnic prejudices. In a multi-ethnic society, however, especially in the context of Malaysia, the giving up of one's cultural identity is often not an easy issue to grapple with for the party who is on the compromising end. The film's representation of intercultural marriage can thus be seen as a confrontation of the real issues that Malaysians face and the possibilities of perceiving human relationships beyond ethnic and cultural boundaries.

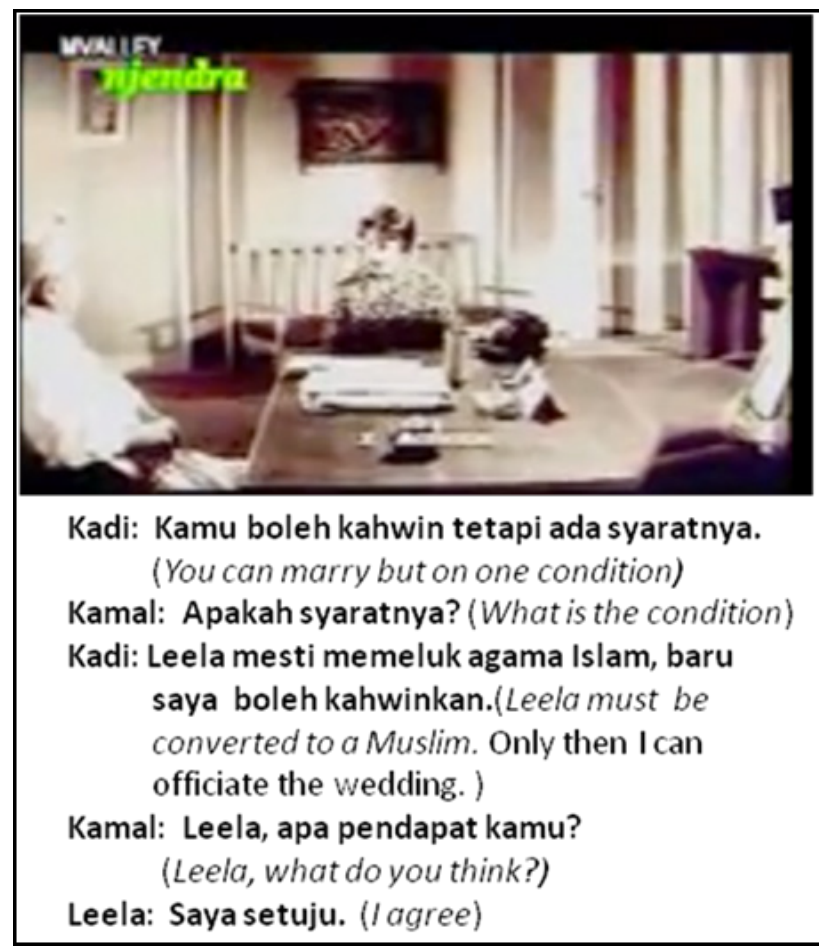

Figure 8: Screenshot of the scene in which the kadi states the obligation of converting to Islam on Leela's part for the solemnisation of her marriage with Kamal in Gerimis. 
There are also instances of adopting the hybrid identity and integrated cultural practices in the mixed marriage portrayed in Gerimis. One of them is shown in Leela's embracing of a hybrid identity in her marriage life. The cultural attires that Leela adorns after being married to Kamal include the baju kebaya and sari that are interchangeably worn, as shown in Figure 9. Cultural attires in films are often seen as the explicit symbols of one's cultural identity. Leela's donning of the Indian and Malay cultural attires in the film is an indication of an assimilated cultural identity which is common among Malaysians in mixed marriages. Having been assimilated into the Malay culture and religion, Leela displays the integration of her own Indian ethnic identity and the Malay cultural identity that she has accepted as part of her own. In another instance, Kamal also displays cultural integration as he learns a few Tamil words and code switches between Tamil and Malay when he converses with Leela. Before he goes out to work, he greets Leela with the Indian expression, "Vanakam" (an Indian word to wish others well). Another example of a linguistic code-mixing is seen in Leela's father's use of the Malay language that is mixed with the Tamil language at home. The way in which the code-mixing is done is familiar to Malaysians and reflects the localised identity of Malaysians in adopting multiple languages in their daily conversations. Similar to Sesudah Suboh, the ease in which different languages are portrayed in Gerimis reflects the fluidity in the daily instances of cross-cultural dialogue between Malaysians.

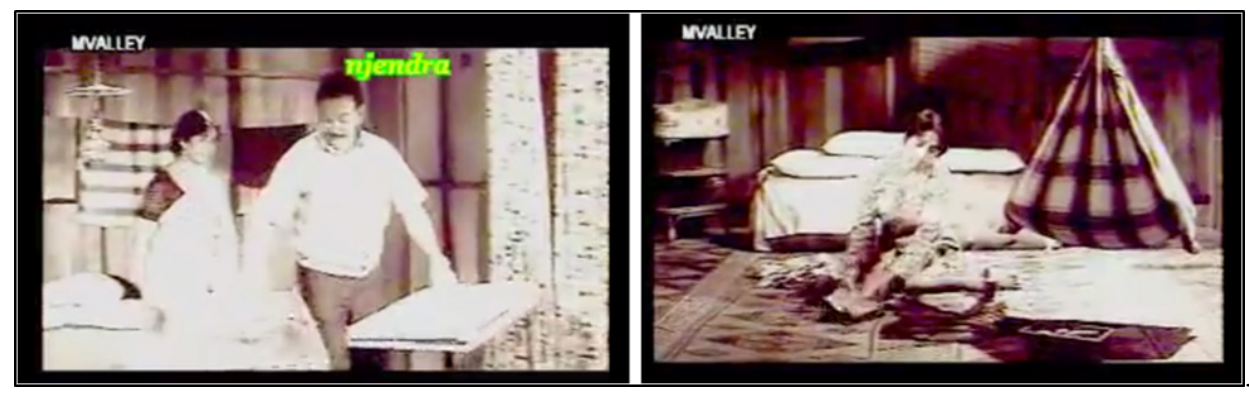

Figure 9: Screenshot of the scenes in which Leela is seen to be wearing sari in the first and baju kurung in the second in Gerimis.

Interestingly, the conflicts and challenges that Kamal and Leela have had to face seem to be unrelated to their ethnic and cultural differences. Gerimis depicts the conflicts and challenges within the inter-ethnic union from other perspectives. Even though Kamal and Leela tie the knot in spite of the objections from their families, the problems that they later encounter in their marriage are not ethnicrelated, but those that are commonly faced in all marriages. Due to his fate of being disowned by his father, Kamal is excluded from the entitlement of the family inheritance willed by his deceased father. To make ends meet, Kamal resorts to 
switching to different jobs from being a painter, to becoming a labourer and later a fishmonger, as he faces the various obstacles of being the sole breadwinner in the family. Jalil, who is the youngest brother of Kamal's father, empathises with what Kamal has gone through and generously receives Kamal, Leela and their baby into his home and entrusts Kamal the responsibility of managing his business. When all seems to be going well for the couple, their marriage is threatened by the presence of a third party, Tinah, Jalil's tenant who refuses to pay her rent. Kamal meets Tinah in his attempt to collect the rental that is due to be paid by Tinah but she, in turn, seduces him to avoid paying the rent. Having failed in her first attempt, Tinah uses black magic in the form of a magic potion that is given by a bomoh (a Malay witch doctor), to lure Kamal into being charmed. Tinah succeeds and Kamal, under her spell, becomes infatuated with her and marries her as his second wife without the knowledge and consent of Leela. The film seems to shift the focus from ethnic differences to polygamy as the latter is represented as one of the bigger challenges of Muslim marriages in multi-ethnic Malaysia, compared to inter-ethnic differences.

The film also showcases how support and love can be given in inter-ethnic relationships. In the midst of the trial and tribulations in Kamal and Leela's wedding, the role of the Malay family is shown to be pertinent. Leela, while struggling to cope with her feelings of dejection and the need to care for her sick child, receives the comfort by her own family and the support given by Jalil and his daughter. The Malay family members stand by Leela, and show their strong disapproval towards Kamal's act of abandoning Leela and their child. Jalil commands Su'ud, his worker, to chase Kamal and Tinah out of his house. Su'ud finally gets the same bomoh to reverse the black magic. Kamal, having regained his normal self, runs back to Leela but it seems to be too late as Leela has returned to her parents' house. Jalil tells Kamal that he is only allowed to his house after he is reconciled with Leela. The extent of the support given to Leela by Jalil at the most difficult time of her marriage indicates the strong ties that are formed between them in spite of their ethnic differences. The fact that Jalil and his daughter do not side with Kamal and Tinah, even though Tinah is a Malay, is significant in the film. The bond between Leela and her Malay in-laws is thus a picture of inter-ethnic solidarity. Even though Kamal's second marriage is lawful under the Islamic law, his family stands by Leela. The portrayal of Kamal and Leela's reconciliation in the end implies the possibilities of inter-cultural assimilation and accommodation in the realities of multi-ethnic Malaysia. 


\section{CONCLUSION}

The analysis of Sesudah Suboh and Gerimis has identified the spaces for border crossings and inter-ethnic engagement in the multi-ethnic realities of Malaysians through the love story narrative. Sesudah Suboh depicts the significant role of non-Malay characters in assisting the Malay characters to be reconciled with each other in the familial setting, whereas Gerimis portrays the Malays helping to heal the broken bond between the Malay and the ethnic Indian, as shown by the constant support of Kamal's uncle that is given in the effort of reuniting Kamal and Leela. The fact that Leela's father, who initially objects to the inter-ethnic union, finally accepts and is reconciled with the couple indicates that inter-cultural accommodation is possible with a change of perspective and the letting go of prejudices. From the analysis, it can be concluded that inter-ethnic engagement largely involves the dynamic process of negotiation and dialogue. The two films demonstrate the importance of cross-cultural engagement, empathy and respect in the meeting of people with different worldviews and acceptance of each other's differences. As films of the golden era were produced just before the major ethnic riot of 1969, both Sesudah Suboh and Gerimis are significant in foreshadowing the importance of cross-cultural dialogue and negotiation at a time when inter-ethnic tensions loomed in the early years of nation building in postcolonial Malaysia.

On the issue of viewership, the question arises as to whether both films were well-received as groundbreaking portrayals of inter-ethnic stories on the early Malaysian screen. Interestingly, Johan (2016) states that "Sesudah Suboh (1966) and Gerimis (1967), both produced by Merdeka Film Studio in Ulu Kelang, did not resonate well with the audience despite introducing non-Malay actors Vera Wee and Chandra Shanmugam". According to Johan, one reason could be that the Malay cinema was beginning to lose its appeal at a time when the Malay film production companies were divided between Malaysia and the new Singapore state. In contrast to the poor reception of the film in the $1960 \mathrm{~s}$, many viewers of Gerimis in recent years seem to show greater appreciation for the film. The film as well as the bilingual Tamil and Malay song that were featured in the film were popular among Malaysians on the eve of Deepavali in 2015. According to Wani (2015), many Malaysians expressed that the song, Pujaanku, "sparked many nostalgic memories for netizens against the current backdrop of racism triggering an outpouring of responses". The appeal of Sesudah Suboh and Gerimis seem to have increased for today's viewers more than the viewers of the 1960s. The films could be more popular now than before due to the heightened sense of inter-ethnic animosity that is evident in various discourses of the media, politics and religious extremism.

Thus, as films are vivid representations of the everyday socio-cultural realities, they are important medium through which inter-ethnic relationships can 
be explored and made to be less of a cultural taboo for all Malaysians. Sesudah Suboh and Gerimis evidently reflect the filmic spaces for negotiating the issues of ethnic differences which are still being represented, negotiated and reconstructed in today's multi-ethnic realities. The analysis shows that the films' stories depict the nation-of-intent of those who desire a more open, engaging and inclusive multi-ethnic Malaysia. The discussion in this paper has attempted to uncover the possibility of seeing the two films as narratives that depict inter-ethnic dialogues and negotiations in the beginning stage of a budding postcolonial nation. As films often represent the socio-cultural realities of the time of their production, they are seen as important socio-cultural texts that reflect the socio-political undertones of the time as well as the everyday realities of the characters. Hence, the films seem to put forth the need for Malaysians to look beyond the inter-ethnic borders that have been historically reinforced from the colonial to the postcolonial eras and to re-discover the spaces that they share as members of a budding nation.

\section{REFERENCES}

Amir Muhammad. 2010. 120 Malay movies. Petaling Jaya: Matahari Books.

Cheah, B. K. 2007. Envisioning the nation at the time of independence. In Rethinking ethnicity \& nation-building: Malaysia, Sri Lanka \& Fiji in comparative perspective, ed. Abdul Rahman Embong, 40-56. Kajang: Malaysian Social Science Assocation.

Hall, S. 2000. Who needs "identity"? In Identity: A reader, eds. P. Du Gay, J. Evans and P. Redman, 15-30. IDE: Sage Publications.

Hamzah Hussin. 2004. Memoir Hamzah Hussin: Dari Keris Film ke Studio Merdeka. Bangi: Penerbit Universiti Kebangsaan Malaysia.

Hassan Muthalib and T. C. Wong. 2002. Gentle winds of change. In Being and becoming: The cinemas of Asia, eds. A. Vasudev, L. Padgaonkar and R. Doraiswamy, 301328. New Delhi: Macmillan India.

Hassan Muthalib. 2013. Malaysian cinema in a bottle. Petaling Jaya: Merpati Jingga.

Hefner, R. W. 2001. The politics of multiculturalism: Pluralism and citizenship in Malaysia, Singapore and Indonesia. Honolulu: University of Hawai'i Press.

Hirschman, C. 1986. The making of race in colonial Malaya: Political economy and racial ideology. Sociological Forum 1: 330-360. https://doi.org/10.1007/BF01115742

Hirschman, C. 1987. The meaning and measurement of ethnicity in Malaysia: An analysis of census classifications. Journal of Asian Studies 43: 555-582. https://doi. org $/ 10.2307 / 2056899$

Hussein Haniff. 1965. Jiran Sekampong. Film. Directed by Hussein Haniff. Malaysia: Cathay-Keris Film Productions. 
Johan Jaaffar. 2016. United colours of Malaysian cinema. The Star Online, 2 May. http:// www.thestar.com.my/opinion/columnists/the-bowerbird-writes/2016/05/02/ united-colours-of-malaysian-cinema-despite-the-language-and-target-audiencethe-involvement-of-nonma/ (accessed 1 August 2016).

Mahyuddin Ahmad. 2011. Between desire and hope: Ethnic relations and the notion of bangsa Malaysia in Gadoh. Kajian Malaysia 29(1): 75-90.

McKay, B. 2011. The golden age. In Fringe benefits: Essays and reflections on Malaysian arts and cinema, eds. Y. S. Guan and J. C. H. Lee, 209-214. Petaling Jaya: Strategic Information and Research Development Centre.

Millet, R. 2006. Singapore cinema. Singapore: Editions Didier Millet.

P. Ramlee. 1961. Ali Baba Bujang Lapok. Film. Directed by P. Ramlee. Singapore: Malay Film Productions Ltd.

P. Ramlee. 1966. Do Re Mi. Film. Directed by P. Ramlee. Malaysia: Merdeka Film Productions Sdn. Bhd.

P. Ramlee. 1967. Sesudah Suboh. Film. Directed by P. Ramlee. Malaysia: Merdeka Film Productions Sdn. Bhd.

P. Ramlee. 1968. Gerimis. Film. Directed by P. Ramlee. Malaysia: Merdeka Film Productions Sdn. Bhd.

Ramani, V. 2005. Plural identities: Reinventions and revisions in Malaysian cinema. Criticine: Elevating Discourse on Southeast Asian Cinema, 15 October. http:// criticine.com/feature_article.php?id=21\&gt (accessed 1 August 2016).

Salleh Ghani. 1961. Sri Mersing. Film. Directed by Salleh Ghani. Singapore: Cathay-Keris Film Productions.

Shamsul Amri Baharuddin. 1996. "Nations-of-intent" in Malaysia. In Asian forms of the nation, eds. Tonnesson S. and H. Antlov, 323-347. London: Curzon Press.

Shamsul Amri Baharuddin, ed. 2012. Ethnic relations module. 2nd ed. Bangi: Institute of Ethnic Studies, UKM.

Uhde, J. and Y. N. Uhde. 2000. Latent images - Film in Singapore. Singapore: Oxford University Press.

Van der Heide, B. 1996. Malaysian movies: The Shaw Brothers meet the Pandava Brothers. In Crossing cultures: Essays on literature and culture of the Asia-Pacific, eds. B. Bennett, J. Doyle and S. Nandan, 101-110. London: Skoob Books Ltd.

Van der Heide, W. 2002. Malaysian cinema, Asian film. Amsterdam: Amsterdam University Press.

Wani Muthiah. 2015. P. Ramlee's "Gerimis" a love and Malaysian story. The Star Online, 1 September. http://www.thestar.com.my/news/nation/2015/09/01/p-ramleesgerimis-a-love-and-malaysian-story/ (accessed 1 August 2016).

Yeoh, S. G. and J. C. H. Lee, eds. 2011. Fringe benefits: Essays and reflections on Malaysian arts and cinema. Petaling Jaya: Strategic Information and Research Development Centre. 